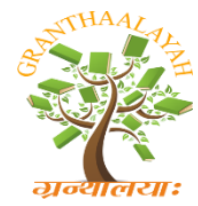
\author{
GRANTHAALAYAH \\ A knowledge Repository
}

INTERNATIONAL JOURNAL OF RESEARCH -

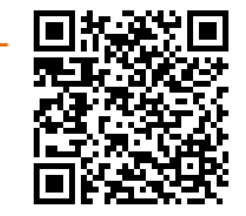

Management

\title{
PROBLEMS OF WOMEN ENTREPRENEURS - WITH SPECIAL REFERENCE TO TAILORS IN ASARIPALLAM, KANYAKUMARI DISTRICT
}

\author{
Dr. C.Subathra *1 \\ ${ }^{* 1}$ Assistant Professor of Commerce, Pioneer Kumaraswamy College, Nagercoil - 3, India
}

DOI: https://doi.org/10.29121/granthaalayah.v5.i2.2017.1748

\begin{abstract}
There is no doubt that we are in the midst of a great revolution in the history of women. Women are major contributions to the 21 'st century's emerging economy. These days the mantra that women seem to embrace is that of women entrepreneurship. Everywhere problem also travels along with prospect. Entrepreneurship is of no exception to this. The condition will be more serious especially with the womenfolk considered. In this paper, the researcher has attempted to study the problems of women entrepreneurs in general and the problems of women tailor in Asaripallam area in particular. Also suggested some valuable solutions to overcome those problems.
\end{abstract}

Keywords: Entrepreneurs; Woman; Problems; Tailors.

Cite This Article: Dr. C.Subathra. (2017). "PROBLEMS OF WOMEN ENTREPRENEURS WITH SPECIAL REFERENCE TO TAILORS IN ASARIPALLAM, KANYAKUMARI DISTRICT." International Journal of Research - Granthaalayah, 5(2), 363-368. https://doi.org/10.29121/granthaalayah.v5.i2.2017.1748.

\section{Introduction}

\section{'The hand that rocks the cradle rules the world'.}

As per census 2011, out of the total population $121 \mathrm{Cr}$ women are there in the country. In Tamilnadu, out of 7.21 $\mathrm{Cr}$ total populations $3.59 \mathrm{Cr}$ women are there. Therefore, development of the Indian economy is not possible without the participation of women like both hands are necessary to do any work properly. It is essential that men and women are given equal opportunities to work, so that they can increase family income in particular and the country's income in general. In India, women have generally confined their profession to activities like teaching, office work, nursing, medicine, social work and the like. Now a days they have entered into professions like engineering and business and they started plugging into industries also and running their enterprises successfully. 
The term Entrepreneur is derived from the French word known as 'entreprendre' which means 'to undertake'. In 18th century this term was first used by an Irishman named 'Richard Cantilon'.

\section{Entrepreneur}

An entrepreneur could be defined as a dynamic agent of change, who is motivated to use resources and skills and to take risks to achieve results in a competitive market. -Joseph Schumpeter.

\section{Entrepreneurship}

The purposeful activity of an individual or a group of associated individuals, undertaken to initiate, maintain, or earn profit by production and distribution of economic goods and services. -A.H.Cole.

Its features are risk bearing, innovation, decision making, achievement orientation, accepting challenges, creative personality and mobilizing resources.

\section{Women Entrepreneurship}

Women entrepreneurs are those who generate business idea, set up an organization, combine the factors of production, operate the unit, undertake risks and handle problems involved in operating a business enterprise.

\section{Problems of Women Entrepreneurs}

Women entrepreneurs face lots of problems at start- up as well as during operating stage like, non-availability of finance, restricted mobility freedom and having to perform dual role one at home and other at work. Technological advancement and information technology explosion have reduced the problem of women entrepreneurs. Along with technological revolution, mental revolution of society is needed to change the attitude of the society and provide women with democratic and entrepreneurial platform.

Women in business are facing many problems to get ahead their life in business. A few problems can be detailed as follows;

1) The greatest deterrent to women entrepreneurs is that they are women. Male dominant social order is the building block to them in their way towards business success.

2) The bankers consider women entrepreneurs as higher risk than men entrepreneurs. The women entrepreneurs are suffering from inadequate financial resources and working capital. The women entrepreneurs lack access to external funds due to their inability to provide tangible security. Very few women have the tangible property in hand. According to a report by the United Nations Industrial Development Organisation (UNIDO), 'despite evidence that women's loan repayment rates are higher than men's, women still face more difficulties in obtaining credit,' often due to discriminatory attitude of banks and informal lending groups. 
3) Women's family obligations also bar them from becoming successful entrepreneurs in both developed and developing nations. Having primary responsibility for children, home and older dependent family members, few women can devote their time and energies to their business.

4) The business success depends on mainly with the support of the family members. The interest of the family members is a determinant factor in the realization of women folk business aspirations.

5) Another argument is that women entrepreneurs have low-level management skills. They have to depend on office staff and intermediaries, to get things done, especially, the marketing and sales side of business.

6) The male and female competition is another factor, which develop hurdles to women entrepreneurs in the business process. Despite the fact that women entrepreneurs are good in keeping their service prompt and delivery in time, due to lack of organizational skills compared to male entrepreneurs women have to face constraints from competition. The confidence to travel across day and night and even different regions and states are less found in women compared to male entrepreneurs. This shows low-level of freedom of mobility among them.

7) Knowledge of alternative source of raw materials availability and high negotiation skills are the basic requirements to run a business. Getting raw materials from different source with discount prices is the factor that determines the profit margin. These two factors affect the women entrepreneur's business adventures.

8) Knowledge of latest technological changes, knowhow and educational level of the person are significant factor that affect business. Low literacy rate of women in India is found at low level compared to male population.

9) Low level risk taking attitude is another factor that affects the success of any business.

10) Achievement motivation of the women folk found less compared to male members.

\section{This study focuses on women tailors in Asaripallam area}

Woman with a business in hand is surely considered to be a noteworthy person in any society. She may have self-confidence, courage in making any decision depending or believing the income she earns.

In this context, 40 respondents (women tailors) were identified in Asaripallam area. Necessary data were collected from them directly. A properly set questionnaire was framed by the researcher as per the objectives of the study. Simple random sampling method was used to collect the data. The collected data were analysed with the help of various statistical measures such as Percentage and Garret ranking technique. The formula used for Garret ranking method is

Percent position $=\frac{100(\mathrm{Rij}-0.5)}{\mathrm{Nij}}$

\section{Objectives of the Study}

The following are the objectives of the study.

1) To study the problems of women entrepreneurs in general. 
2) To trace out thoroughly the problems of women tailors in Asaripallam area.

3) To analyse the problems of women tailors in Asaripallam area.

\section{Problems of Women Tailors in Asaripallam Area}

As the tailors sit and do the work for the whole day they are affected by back pain, shoulder pain, leg pain, hand pain and eye pain in general and specifically uterus problems. Among the numerous problems, the significant problems faced by the women tailors are presented in Table1.

Table 1:

\begin{tabular}{|l|l|l|l|l|l|l|l|l|}
\hline S. No & Problems & \multicolumn{3}{|l|}{ Ranks } & \multirow{2}{*}{ Total } \\
\cline { 3 - 8 } & & 1 & 2 & 3 & 4 & 5 & 6 & \\
\hline 1 & Physical inconvenience & 30 & 2 & 7 & 1 & 0 & 0 & 40 \\
\hline 2 & Time management & 0 & 2 & 4 & 14 & 7 & 13 & 40 \\
\hline 3 & No care given to in-laws & 0 & 0 & 1 & 7 & 17 & 15 & 40 \\
\hline 4 & Not caring for the health of family members & 0 & 0 & 2 & 14 & 15 & 9 & 40 \\
\hline 5 & Pending of household responsibilities & 6 & 18 & 14 & 1 & 1 & 0 & 40 \\
\hline 6 & Not keeping the house neat & 4 & 18 & 12 & 3 & 0 & 3 & 40 \\
\hline
\end{tabular}

(Source: primary data)

Table 2:

\begin{tabular}{|l|l|l|l|}
\hline S. No & Problems & Garret mean score & Rank \\
\hline 1 & Physical inconvenience & 71.5 & I \\
\hline 2 & Time management & 41.57 & V \\
\hline 3 & No care given to in-laws & 40.97 & VI \\
\hline 4 & Not caring for the health of family members & 44.22 & IV \\
\hline 5 & Pending of household responsibilities & 61.3 & II \\
\hline 6 & Not keeping the house neat & 57.07 & III \\
\hline
\end{tabular}

(Computed data)

It can be inferred from the above table that the main problem faced by the respondents because of their tailoring work, physical inconvenience ranks first, the problem of pending of household works ranks second, not keeping neat the house ranks third, and not caring for the health of family members, time management, not caring the in - laws rank respectively fourth, fifth and sixth.

\section{Findings of the Study}

- The main problem of the women tailors is physical inconvenience.

- The second problem faced by them is pending of household responsibilities.

- The third ranked problem is not keeping neat and clean.

- The fourth problem is not caring for the health of family members.

- The fifth problem is time management, and

- No care given to in -laws is the last problem. 


\section{Suggestion}

Right efforts from all areas are required in the development of women entrepreneurs and their greater participation in the entrepreneurial activities. Following efforts can be taken into account for effective development of women entrepreneurs.

Adequate arrangements must be made for the supply of credit facility at concession rate for the women entrepreneurs in view of their growing needs.

Creating provision of micro credit system and enterprise credit system to the women entrepreneurs at local level is the need of the hour.

The mental revolution of society is needed to change the attitude of the society and provide women with democratic and entrepreneurial platform.

Even though they mention their problems the effect is very meagre comparatively to the benefits. So in the words of them, it is suggested that as a women, everybody should know to stitch everybody's cloth. And also economic independence is another important thing which should be there in every family especially with the womenfolk. That is needed for the development of the whole nation.

\section{Conclusion}

Entrepreneurship is presently the most discussed and encouraged concept all over the world to overcome economic challenges. Women being the vital gender of the overall population have great capacity and potential to be the contributor in the economic development of any nation. Developing countries are definitely in dire need to encourage women entrepreneurship as women workforce is promptly available to exploit the unexplored dimensions of business ventures. At this juncture, effective steps are needed to provide entrepreneurial awareness, orientation and skill development programs to women.

Women entrepreneurs must be moulded properly with entrepreneurial traits and skills to meet the changes in trends, challenges in global markets and also be competent enough to sustain and strive for excellence in the entrepreneurial arena. Our Government should primarily focus on entrepreneurial educational programs in order to develop women entrepreneurs.

'Empowering women is a prerequisite for creating any nation, when women are empowered, society with stability is assured. It is quite essential as their thoughts and their value systems lead to the development of a good family, good society and ultimately a good nation'. - A.P.J. Abdul Kalam.

\section{References}

[1] Dr. Radha (2009) Entrepreneurial Development- Prasanna \& co, Chennai.

[2] International journal of business intelligence and management.

[3] Jose P., Ajith kumar.Paul T.M., (1994) Entrepreneurship Development, Himalaya Publishing.

[4] Journal; The JUP Journal of Entrepreneurship Development- June 2012. 
[5] Medha Dubhashi Vinze( 1987) Women Entrepreneurs in India; A socio- economic study of Delhi- 1975-76, Mittal Publications, New Delhi.

[6] Renuka v. (2001) Opportunities and challenges for women in business, India Together, Online Report, Civil Society Information Exchange Pvt. Ltd. 